測定法

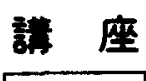

\section{電流一電位曲線の測定 $(1)$}

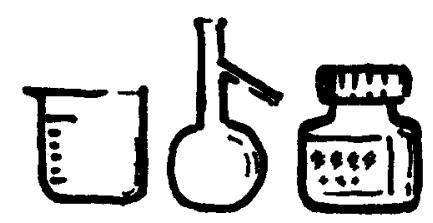

1 はじめに

白金電極はそれ自身が多くの電解得に対して不溶性 で，また多くの反応系に電極触媒作用を示すことから電 極を取り扱う上での基本となる。ここでは基本的な白金 電㮔の作り方之処理方法，ならびに電極への水素および 酸素吸着特性のボルタングラムについて述べる。

\section{2 白金電橝のいろいろ}

白金車極の形状としては
a) 線状
b) 板状，ディスク状，リング状
c) 網状
d) 球状

表面の状態を考えると
a) 多結晶
b) 単結晶
c）アモルファス (白金黒)

などが考えられる.実験の必要性に応じてこれらの形状， 形態の中から還抧する.

\section{1 平板而橝の作り方}

板状電極は表面皘を大きくする必要があるときに用い られる，白金板に通電するため，リード線として白金線 を接続する必要がある，リード線を出すためには，図 1 に示すように白金板と白金線をステンレスの板上にのせ ハンドバーナーの酸化炎で赤熟し，ハンマでかるくたた くと圧譄できる.

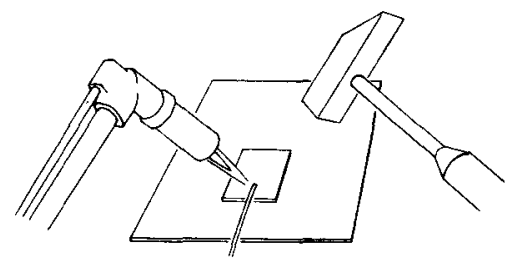

図 1 バーナーとハンマーによる白金板と白金線の 接続方法

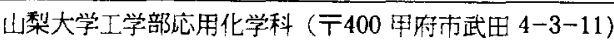

\section{白金電極一一作り方、洗い方、 乥して光の電気化学的特性}

白金網の場合も同様にリード線を取り付ける.このと きバーナーで加熱しすぎて白金板および線を溶かさない ように十分注意する.さらに圧着点をハンマーで強くた たきすぎると加熱した白金はやわらかいので圧着部が薄 くなり取れ易くなる。また図 2 のように白金板 $(0.5 \mathrm{~mm}$ 厚以上）では $0.5 \sim 1.0 \mathrm{~mm} \phi$ 白金線とバーナーで溶 接する方法もある. 白金の加熱溶時には強い光が出るの で目のために保護眼鏡をかける必要がある。この方法で は白金板に不純物が入る心配がない，白金板と白金線を 接続したら白金線をやわらかくするためと，表面の不純 物をとり除くために，全体を $1000^{\circ} \mathrm{C} \sim 1200^{\circ} \mathrm{C}$ でアニー ルする。このまま使用してもよいが，ガラス，ブラス ティック等にマウントすると使い易い.

比較的精密な実糇に用いる場合にはガラスに封入する.

使用するガラスは、ソーダガラスとする. 他のガラス では膨張率が白金のそれと遣うためわれやすい，白金板 が大きく重いときは強度を增すために白金板と白金線の 圧善部までソーダガラスで覆うよよい，バーナーの炎は 小さくし，十分時間をかけて溶封する.

電極の表面積をさらに增加するためには白金黒付けす る.

電極を使用する条件によってはより简単な作りかたで よい場合もある，そのときは，白金板と銅線をハンダ付 けし，その回りを接着戍のエポキシまたはシリコン樹脂 でぬりかため，銅線が電解液にふれないようにする。

\section{2 線状需極の作り方}

比較的小面積の白金電極として用いるときに線状電極

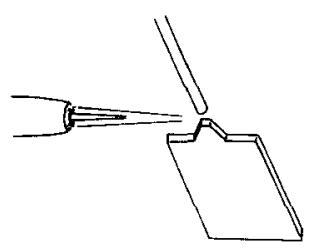

図 2 白金上白金線の溶接

白金板は白金トングスで保持する 


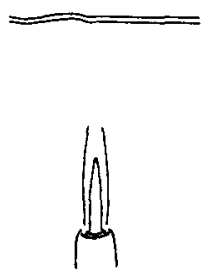

a

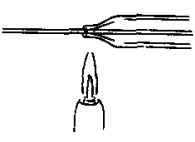

c

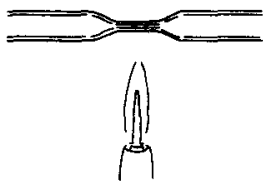

b

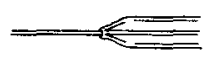

図 3 白金線のソーダガラスへの封入 を用いる.

種々の径の白金線を用い線状電極を作るには図 3 に示 すようにソーダガラスに封入する.ソーダガラスは 6

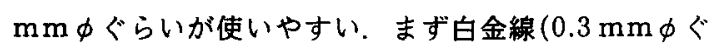
らいがよい) を酸化炎でやきなます（図3 a). 炎の近く では白金線がとけてしまうので注意する，特に細線は炎 のかなり上部で注意深く焼きなます。

ガラス管をひきのばし，図3bのように白金線が入る ほどにする．焼鈍した白金線を直っすぐにし，ガラス管 に入れ小さな炎でゆっくり封止するガラス部を溶かす (図3 c).このとき白金線を溶かさないようにしながら 十分溶着した後，炎から順次遠ざけて泠却する，白金線 が $1 \mathrm{~mm} \phi$ 以上になると徐冷が大事である. 封人点のガ ラスの肉厚はあまり厚くしない万がよい，パイレックス ガラスでも肉厚が薄ければ封入できるが, 溶融温度が高 いので細い白金線は溶け易い，封止した白金線は白金表 面棈の必要に応じて長さを決めカットする.

微小電極の場合は，ガラス封入部をエメリーペーパー でみがき断面を利用する。

\section{3 テフロン等で往った西栖}

テフロンホルダーを作りその中に白金ディスクを入れ る雪極はディスクの交換が容易である.

リング雪極、ディスク钘極等はテフロンを施盤加工し 潅を作る．その䧿に白金電極を王入する.

テフロン熟収縮チューブに白金線を入れ，加熱し覆う 方法もある.

\section{4 白金付白金国柾}

標準水菜雨極等に用いる場合，白金板または白金網に 白金黒付けし表面穔を增加させると安定した電位が得ら れる，製法は塩化白金酸 $\left(\left[\mathrm{H}_{2} \mathrm{PtCl}_{6}\right]\right) 3 \mathrm{~g}$ を $100 \mathrm{~cm}^{3}$ の水に溶かし，塩酸を 1 滴入れ，これに $30 \mathrm{mg}$ ぐらい の酢酸鉻を加えたものをメッキ液とする.
白金黒付けする電極を2つ用意し，メッキ液を入れた ビーカー中に数センチメートル間隔をあけ平行に是き， 数 $10 \mathrm{~mA} / \mathrm{cm}^{2}$ で電解を行い,1分おきに極性を反転さ せる. 5分ぐらいで黒色となるので膜厚の必要に応じて時 間を長くする.蒸留水で水洗後, $0.5 \mathrm{MH}_{2} \mathrm{SO}$ ，で陽分極， 陰分極を綝り返し，鉛等を取り除く，蒸留水でよく洗浄 し用いる.

\section{3 電極の洗い方}

ソーダガラスで封入した電極では作った後，表面は手 アカ，空気中の油，はこり等が付いている．まず水洗い し，クロム酸混液(浱硫酸 $1 \mathrm{dm}^{3}$ に重クロム酸力リウ ム $30 \mathrm{~g}$ を溶解）に数時間つけ蒸留水で洗浄する。この とき手のよごれがつかないように十分注意する.手の油 はきれいな表面にすぐに拡散し，水をはじくようにして しまう，白金電極の触媒活性等を測定する実馀等，精密 な条件で行なう必要のないもの，たとえば電解用の対極 等は電極を清净化した後，そのまま用いてよい.

エポキシ等で賈ったものは水洗後, 蒸留水でよく洗浄 する.この電極は電解酸化，迤元を行ない，電気化学的 にクリーニングする，電解液はエポキシ等の樹脂をおか さないものしか使用できない，精密な実呀ではガラスに 封入したものを使用するべきである.

テフロン系の樹脂を使った丽極では、テフロン采の㰾 脂は耐莧品性がよいため. クロム混液クリーニングがで きる.

しかしながら、テフロンと白金の接続部分の密書性を 注意しておかない上，使用時のその部分から酸素の拡散 等があり精密実験ではその影雪を考えなければならな い. 電気化学的に酸化遇元を繰り返しても表面に析出し た贯金属元素上か，微量の金属，カーボン等は除くこと が困難である.この表面層を取り除くには熱王水で 5 分 ぐらいエッチングするとよい，エッチング後蒸留水で洗 浄する.

\section{4 白金表面への水素吸着電気量}

白金電極の真の表面皘はみかけの表面積より大きい， 電極表面が鏡面であっても表面原子数は幾何学的表面積 に比べ 2〜3 倍である.さうら白金黒を付けた電極では 数百倍となる.

電極触蝶活性を比較する場合，表面原子数を基準に考 えることが多い，そこで白金表面原子に単原子展水素が 吸着する電気量から真の表面積を計算している. 一般に $1 \mathrm{~cm}^{2}$ 当たり $210 \mu \mathrm{C}$ として計算している場合が多い ようである.

これは白金表面を単結晶の低指面でできているとして 算出されたもので（100）面之ほぼ同じ值を用いている. また酸素吸着量からも真の表面稓は算出できるが，白 
表 1

\begin{tabular}{|c|c|}
\hline $1 \mathrm{~cm}^{2}$ 当りの原子数 & マイクロクーロン $/ \mathrm{cm}^{2}$ \\
\hline $\operatorname{Pt}(110) \quad 1.31 \times 10^{15}$ & 208 \\
\hline $\mathrm{Pt}(111) \quad 1.51 \times 10^{15}$ & 242 \\
\hline $\operatorname{Pt}(110) \quad 0.93 \times 10^{15}$ & 148 \\
\hline 多 結 晶 & 210 \\
\hline
\end{tabular}

金表面への酸素吸着はよ゙こまでが単原子層吸着なのか はっきりしないのであまり用いられていない。

\section{5 電気化学的測定}

白金電極をきれいに洗った後，ポテンシォスタットで ボルタングラムを測定してみる.

湘定に用いるセルの洗浄はクロム酸混液で一昼夜つけ 蒸留水でよく洗浄する. 電解液，ガス類は高純度のもの を用いる必要がある．特に Sweep rate が小さくなる と不純物，溶存酸素の影帮が大きくなる，溶存酸素は $\mathrm{N}_{2}$ ，または Heガスをバブルし電解液中から除く．約 30 分ぐらいのバブルでほぼ除去できる. Sweep rate が $50 \mathrm{mV} / \mathrm{sec}$ では $0.1 \mathrm{~cm}^{2}$ 程度の白金者極ではポテン シォスタットの感度は $1 \mathrm{~mA} /$ フルケケル以下となる ので，外部からのノイズ対策を行う必要がある.

因 4 に白金線 $(0.3 \mathrm{~mm} \phi \times 10 \mathrm{~mm})$ をソーダガラス に封入した電極において不純物が吸羊した白金電極のボ ルタングラムを示す．不純物の吸着によって水菜酸化波 (a)が小さく、酸亲吸着波(b)が変形し，高電位側にシ フトする、酸萃吸著波(c)は吸普不純物がすべて溶解し ないため小さくなり，水素吸萧波(d)も同様に小さい.

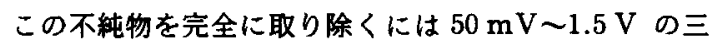
角波を数十回綝り返す必要がある.

図 5 に三角波パルスを 10 回加えクリーニングした白 金雷極のボルタングラムを示す. 白金表面原子数は鉡線 に示した部分で, $50 \mathrm{mV}$ から $400 \mathrm{mV}$ で脱離する吸畕 水菜から箕出する．斜線部の表面稓をプラニメー夕等で

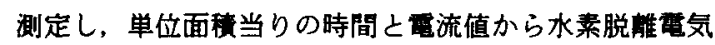
皇 $Q \mu \mathrm{C}$ を出す. この值を $210 \mu \mathrm{C} / \mathrm{cm}^{2}$ で割れば表面 䅧 $A$ が出る。

$A=Q / 210 \mathrm{~cm}^{2}$

で桓に三角波パルスを加えると䡒気化学的に表面をク リーニングすると同時に表面槂が增加することも考えな ければならない。これは表面に出ている白金原子の卧列 状腎が酸化通元をくりかえすと容易に変化し, ボルタン グラムも同時に変化する.

図 6 に球状単結晶のボルタングラムを示す.多結晶の それと著しく翼なることが明らかである，さらに，配列 状意によって触媒活性も著しく䢖うことがわかってきた ので，今後，表面原子数一定で比较するのと同様，表面 配列状意も基準をもうけて比較する必要があるだろう。

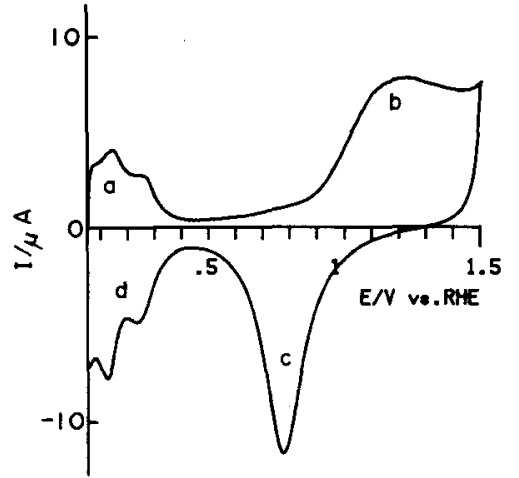

図 4 不純物が吸着した白金電極でのボルタングラ $\angle(50 \mathrm{mV} / \mathrm{sec})$

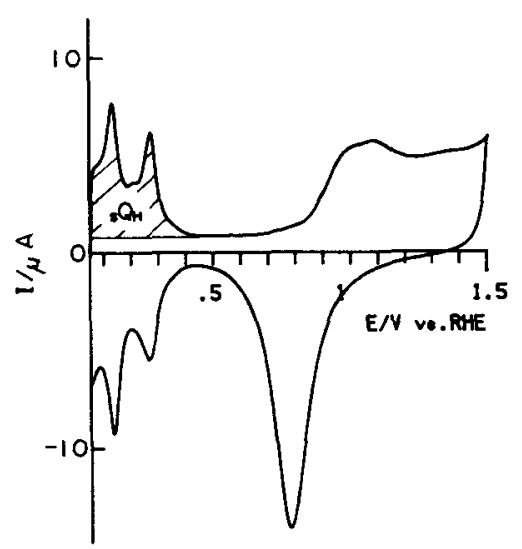

図 5 白金表面原子数の算出方法

二重局を除く水素波の電気息から求める

(三角波パルスで表面をクリーニンク゚)

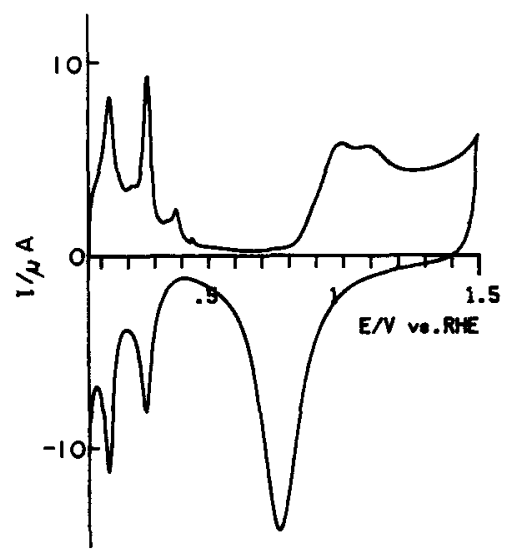

図 6 球状白金単結晶のボルタングラム $(50 \mathrm{mV} / \mathrm{s})$ バーナーで $1500^{\circ} \mathrm{C} 5 \mathrm{sec}$, 加熱後, 水素中で冷却 